\title{
Plant introduction and hybridisation in colonial New South Wales: the work of John Carne Bidwill, Sydney's first director
}

\author{
D.J. Mabberley
}

\begin{abstract}
Mabberley, D.J. (Department of Plant Sciences, University of Oxford, Oxford OX1 3PN; and Rijksherbarium, University of Leiden) 1996. Plant introduction and hybridisation in colonial New South Wales: the work of John Carne Bidwill, Sydney's first director. Telopea 6(4): 541-562. A brief biography of J.C. Bidwill, the first Director of the Sydney Gardens, based in part on previously unpublished manuscript sources preserved at Royal Botanic Gardens Kew and in the Mitchell Library Sydney, is presented. Bidwill's scientific impact is assessed and there is an appendix of plants named after him; the hitherto unplaced Bidwillia is perhaps referable to Trachyandra (Asphodelaceae).
\end{abstract}

\section{Introduction}

'He is, besides being an excellent botanist, a man of general science, a very skillful horticulturist' - William Macarthur on J.C. Bidwill, 17 September 1847 (Macarthur Papers 37(B) Sir William Macarthur Letterbook 4 viii 1844-7 vi 1850 f. 296, A2933-2 Mitchell Library).

In celebrating Lawrie Johnson, here his interest in the history of botany, it is perhaps of some value to examine the career of one of his predecessors as Director of the Sydney Gardens - the first holder of that title, John Carne Bidwill (1815-1853) — as it highlights a number of features of nineteenth-century colonial life and attitudes. Although Bidwill is commemorated in the technical name for the well known bunyabunya pine, Araucaria bidwillii, as well as in the name of a Sydney suburb, he has perhaps so far been rather little-appreciated as a botanical and horticultural pioneer, while even his name is spelled wrongly in the names of the most commercially significant plants purporting to commemorate him.

Having stumbled on a previously unlisted binomial commemorating Bidwill some years ago (Mabberley 1978) and more recently had cause to ascertain the correct name for the single species of the remarkable Australian endemic family Akaniaceae (Gadek et al. 1992), which turned out to be Akania bidwillii (Mabberley 1989: 707), I became interested in the career of their little-known eponymous hero and here set down my findings to date. The following must be seen as merely amplifying the standard secondary sources (especially Herbert (1966) and references therein) through the examination of the rich MSS holdings at the Mitchell Library, Sydney, Royal Botanic Gardens Kew and elsewhere. However, a full assessment of Bidwill's short life can only be made after appraisal of other MSS sources. Moreover the significance of his hybridisation experiments can only be evaluated by those expert in the genetics of the groups concerned. In addition, Professor R. Clough of Double Bay NSW is investigating further Bidwill's hybridising work in Australia and has had the opportunity to delve into aspects of his life not covered here. 


\section{Devon to New South Wales}

At the end of September 1846, Robert Brown (1773-1858), then the doyen of Australian botany, made a roundabout journey from London to visit his geologist friend, Sir Richard Vyvyan, the Tory MP, who lived in Cornwall (Mabberley 1985: 356). On the way he stayed at the Half Moon Hotel, Exeter, whence he visited the great Devon nurseries of Veitch and of Lucombe, Pince \& Co. ${ }^{1}$. He walked out to the latter, famed for the raising of the hybrid Lucombe Oak, situated in St Thomas's, Exeter and there met Robert Taylor Pince (1804-71), 'an accomplished botanist', who had married Lucombe's niece, and 'added materially to the variety of the Exeter Nursery's collections by judicious hybridising of well known species' ${ }^{2}$. Pince, who was from an old Exeter family of gardeners, had joined the firm before 1828 (Harvey 1988). By the time of Brown's visit, James Mangles could write that the firm was one of the principal nurseries in England. It was one of those firms which pioneered the despatch of collectors and the introduction of exotics in the 1830s and, by the next decade, had established introductions from Mexico, Brazil, Sierra Leone and Australia. In 1835, at the sale of Colvill's nursery at Chelsea, Pince had bought up the stock of gladiolus hybrids ('G. $\times$ insignis', Barnard (1972)) and a little later sent illustrations of the hybrid 'Gladiolus ramosus' as well as $G$. $\times$ insignis to Paxton's Magazine of Botany (published in vol 6(1839)99 \& 7(1840)223). Pince showed Brown around his collection, which Brown praised, especially its conifers.

It would appear that Pince's work is the background for Australia's pioneering hybridist, John Carne Bidwill, for Bidwill was born at St Thomas's in February 1815, the eldest son of Joseph Green Bidwill, a businessman ('share-broker, superintendent-registrar and joint clerk of St Thomas's Union' ${ }^{3}$ ), and his wife Charlotte Wilmot Bidwill, second daughter of John Carne, an author of Falmouth, Devon ${ }^{4}$ (Bidwill \& Woodhouse 1927, ch. 14). On 4 April 1832, Bidwill had sailed from Plymouth to Canada on the Exmouth but returned in November 1834. He seems to have been back at St Thomas's when the gladiolus work was being carried out by Pince. Early in 1838, he obtained a letter of introduction from Lord Glenelg (1778-1866), Secretary of State for the Colonies, to Major Thomas Mitchell (1792-1855), Surveyor-General and explorer, then in London ${ }^{5}$. Mitchell in turn wrote a letter of introduction to the Colonial Secretary in New South Wales, Edward Deas Thomson (1800-1879), pointing out that Bidwill was 'respectably connected in Devonshire'. Armed with this, Bidwill, travelling with his sister Elizabeth (born 1817, later Mrs Thomas Digby Miller), set off for New South Wales on the Arachne, a barque of 320 tons $^{6}$ on Good Friday 13 April 1838 in the interests of his father's mercantile business' (Bidwill \& Woodhouse l.c.).

He arrived later that year, intending to settle on the land near Sydney, applying for about 2000 acres at 5/- an acre on 13 December (Bidwill \& Woodhouse 1927: 114). In a few days came the Governor's approval for his purchase but there was a delay in the surveying and he took the opportunity, whilst waiting, to make some 'rambles' in New Zealand. It would seem that during his time in Sydney he was collecting seeds, which were received in England in 1839 and raised by Joseph Knight at his Chelsea nursery; Podolobium ilicifolium (Leguminosae) at least was illustrated by Jane Loudon in her Ladies' Magazine of Gardening (1: t. 8, 4, 1841; Mabberley 1978).

\section{First New Zealand travels}

The Bidwill firm was involved in the trade between New South Wales and New Zealand, there being a small European settlement at the Bay of Islands, whither 
Bidwill went in February 1839. He sailed to Tauranga in the Bay of Plenty, using it as a base and walking to Rotorua with seven Maoris and, at least at first, a white interpreter. He was collecting both herbarium specimens and live plants, finding near Rotorua the scented Easter orchid, Earina autumnalis, which he was to bring back alive to England ${ }^{7}$. He pushed on to Taupo, where only one European had ever been seen (and that was only three weeks previously), carrying medical supplies for the Maoris (Andrews 1990). Crossing Lake Taupo, he reached Lake Rotoaira, exploring the spurs of Tongariro before being recalled in April.

He was thus the first European to collect plants in the interior of the North Island; he was also the first European to ascend the cone of the active volcano Ngauruhoe (Anderson 1958) and perhaps the first man to do so as the Maoris would not climb it. The firewood used during the ascent was gathered from plants now known as Halocarpus bidwillii (Podocarpaceae) and Brachyglottis bidwillii (Compositae). Among the other plants he collected were Raoulia australis (Compositae, his specimen preserved at K), so small that he took it for a lichen, and a number of species like Acaena microphylla (Rosaceae) and Celmisia spectabilis (Compositae) which he would have liked to have introduced to British gardens. Having not had the blessing of Chief Te Heuheu to climb the mountain, there was in consequence a difficult meeting between the two men, apparently with distrust and lack of understanding on both sides.

Despite the danger, Bidwill survived to write an account of his experiences, Rambles in New Zealand (1841), which is a very readable bouncy narrative but includes much original information on the North Island, especially important being observations on agricultural practices, notably the effects of burning. Reprinted in 1952 in a limited edition, the original is now a very rare and valuable book, though perhaps some 500-600 copies were printed in London (Bidwill 1952). The copy presented to his sister Elizabeth has its original 'butcher-paper' cover and is preserved in the Mitchell Library, Sydney and another in original binding is held at the library of Rhodes House, University of Oxford.

During his stay Bidwill met the resident botanist, the Reverend William Colenso (1811-1899) and, being recalled to Sydney in April, took a consignment of living and preserved plants with him, losing a few of the live ones during the voyage (Bidwill and Woodhouse 1927: 114). He sent his best set of herbarium specimens to John Lindley of the Horticultural Society of London with a less complete one to William Hooker. Lindley published none of Bidwill's findings and many of his discoveries were for a time credited to Ernst Dieffenbach, whose collections were made later.

Meantime the Colonial Government of NSW had increased land prices to 12/- per acre though surveyed land was still to be sold at the original price. Bidwill discovered to his consternation that the delays meant his land had not been surveyed and on 15 July 1839 he wrote (Bidwill \& Woodhouse 1927, Ch. 14,15) that negotiations with the Government over his case were unsuccessful; he never became a station-owner. In 1840 he was in New Zealand once more, having been sent to Port Nicholson, Wellington, and collected more plants. He accompanied E. Jerningham Wakefield on an expedition by sea to Wanganui (Wakefield 1908: 284-290), collecting many shells. He supported the move for Wellington to become the capital and bought land there 'at a high price' to demonstrate his backing. During this visit he met Maoris who remembered his ascent of Ngauruhoe and knew him by the name of the mountain (Bidwill \& Woodhouse l.c.). These experiences may have induced him to encourage his brother Charles Robert to settle in New Zealand, for 'Robert' too had left England for Australia in November 1840. John Bidwill now added a little to his Rambles (the preface is dated Sydney 25 August 1840), the dedication to the Earl of Devon, Governor of the Plymouth New Zealand Company, being dated June 1841. 
Some 60 of his specimens from the Nelson area are preserved in Hooker's herbarium at Kew (H.H. Allan in Bidwill 1952: 13; see also Appendix) including some from Lindley's herbarium, about 20 from the Tongariro massif including ' 133 ' Lepidothamnus laxifolius (Podocarpaceae, though Bidwill at first took it for a moss), '65' Dracophyllum recurvum (Epacridaceae), '50' Hebe tetragona (Scrophulariaceae) and, from Lindley's herbarium, Podocarpus nivalis (Podocarpaceae).

\section{The Bunya-Bunya Pine}

Hooker's son Joseph on Ross's voyage of the Erebus and Terror was in Sydney in July and August 1841. Bidwill accompanied him in his rain-dogged excursions in the area, notes sent to Hooker on the Erebus at Sydney being preserved at Kew ${ }^{8}$. Already the former Colonial Secretary, Alexander McLeay of Elizabeth Bay House had persuaded Bidwill to collect leguminous fruits for George Bentham and Bidwill duly wrote to Bentham on 15 Feb $1841^{9}$ apologizing for sending only material from the Sydney area and adding 'I myself am more a lover of gardens and flowers than a botanist' but he seemed happy to supply materials for those whose research was for the benefit of the world at large. He added that he had collected material of a plant possibly representing a new genus allied to Acacia, but the practical man resurfaces in his pointing out that it is probably not worth introducing NSW wattles to England because of the climatic differences but that more of both them and eucalypts could well be established in the Mediterranean.

Bidwill's firm sent him to Moreton Bay, now part of Queensland, whence he wrote to Captain Phillip Parker King (1791-1856) at Port Stephens ${ }^{10}$ (Maiden 1908) about a large new waterlily he had discovered (later described as Nymphaea gigantea) as well as a number of potentially useful fruit trees. He also described the bunyabunya pine, which had been discovered by Andrew Petrie (1798-1872) in 1838 and had become known in Queensland as 'Pinus petrieana' (Herbert 1966). The seeds were an important food for the local Aborigines; Petrie seems to have sought the tree out and he possibly gave material to Bidwill for identification because of the latter's by now acknowledged talents as a botanist (Maiden 1906b).

Bidwill's account of a new species of Araucaria (the bunya-bunya, later named A. bidwillii) in a letter was published over the name ' $\mathrm{H}$. Bidwill' (his hand is not the easiest to decipher) in Tasm. J. Nat. Sci. 1(1842) 404, the same letter (from 'Sidney'), dated 5 July 1841, sent with a twig bearing male cones to London also appearing in Ann. Mag. Nat. Hist. 8(1842)439. Appended to both is an interesting note on Nuytsia floribunda (Loranthaceae), Bidwill recording that the only specimen in the Botanic Gardens flowered every year but set few seeds. Sowing them gave no success but he found two seedlings in the garden, each with three cotyledons, perhaps the earliest observation of this phenomenon. Another Queensland find was his 'Jasminum linoides' which his friend Edward Macarthur Bowman (see below) later proposed calling J. bidwillii ${ }^{11}$.

\section{$X$ Amarygia (? X Amaristetes)}

Bidwill was on good terms not only with McLeay but also other members of the leading NSW families. He corresponded regularly with King at Port Stephens, where he was an intimate of the family, giving storybooks to King's daughter Elizabeth and encouraging her interest in music as well as botany ${ }^{12}$, and seems to have followed Pince's example by making many gladiolus crosses there as he did at Ravensmouth, Dr James Bowman's home in the Hunter Valley, where he became a close friend of 
Bowman's son Edward, the nephew of William and James Macarthur. The Macarthurs were, like Bidwill, originally from Devonshire.

Bidwill did his own hybridizing experiments too, but where he did so has been somewhat obscure up until now, as he is not known to have had a permanent address in Sydney. It seems that at this time he began hybridizing amaryllids at Camden Park, the home of William Macarthur (Traub \& Hannibal 1960), who was to become his close friend and supporter. It has been assumed that most of Bidwill's work must have been done there or, later, at the Botanic Gardens. From allusions in Bidwill's correspondence it seems that he was based some way out of Sydney and later ${ }^{13}$ there is reference to Clovelly, Watson's Bay. This house, named after a Devonshire village, had been built as a 'marine villa' in 1834 for Thomas Watson and was leased in 1838 by Hannibal Macarthur, King's brother-in-law, who bought it in 1840 (Crosson 1989). A drawing of about this date signed ' $\mathrm{J} \mathrm{Mc}$ ' is preserved in the Mitchell Library ${ }^{14}$, showing the house before the Norfolk Island pine, prominent in F. [C.] Terry's 1853 sketch of The Gap published in Landscape Scenery Illustrating Sydney and Port Jackson, New South Wales (1855), was any size. After the failure of Macarthur's bank in 1843, the estate was eventually bought in 1848 by Governor Gipps's private secretary, Henry Watson Parker (later Sir Henry and Governor of NSW), who married John Macarthur's youngest daughter Emmeline in 1843. They enlarged the property and developed an extensive garden of exotics; moreover amaryllid crosses like those made by Bidwill are associated with Lady Parker (see below). Although Bidwill notes in his 'Cape Amaryllids', a letter to the Gardener's Chronicle (27 July 1850, p. 470) that he first raised seedlings of what became known as 'Brunsvigia multiflora hybrids' (X Amarygia bidwillii (? Amaryllis belladonna $\times$ Brunsvigia orientalis $)=X$ A. parkeri) in February 1841, they did not flower until March 1847. Where were they meanwhile? It has not been possible so far to confirm that Clovelly was for part of the time Bidwill's base but what evidence there is seems to point to it. The house was demolished in 1903 but Norfolk Island pines from the garden survive at the north end of what is now Robertson Park.

Bidwill claimed to have crossed Amaryllis belladonna with species in several other genera of Amaryllidaceae - Ammocharis, Boophone and Brunsvigia and even Haemanthus coccineus, though failing with species of Lycoris and Nerine. In November 1846 (before any of the 'B. multiflora hybrids' had flowered), Macarthur ${ }^{15}$ wrote to Bidwill 'your curious bulb from a seedling belladonna has [produced] two leaves this year like an Haemanthus'. If this was in fact a 'Brunsvigia multiflora hybrid' and not an AmaryllisHaemanthus cross, the remark would support the contention of Hannibal (1994) that the hybrids were crosses between Amaryllis belladonna and Cybistetes longifolia, which has distichous leaves adpressed to the ground like those of Haemanthus spp. In the catalogue of plants growing at Camden Park in $1845^{16}$ 'Amaryllis longiflora' (? Cybistetes longifolia) is listed, though it is not in the 1843 edition but seems to have been available earlier to at least Alexander McLeay at Elizabeth Bay. If the parentage is thus, the hybrids should be referred to the hybrid genus $X$ Amaristetes, but so far the lengthy procedure to repeat the alleged cross has not been completed. The plants, which are now grown all over the world (often incorrectly spelling Bidwill's name), were first distributed commercially by the Sydney firm of J. Baptist and Sons in the 1860s.

\section{Return to England}

Bidwill sailed for England via Cape Horn in February 1843 with a case of plants of his own and one from Camden as well as six parrots, four of them little cockatoos. His plant-case was protected only with wire mesh unlike the Camden one which had bars and many of the box's panes were lost ${ }^{17}$. He had living bunya-bunya pines 
but as he wrote to Edward Bowman, the hot Sydney sun before the voyage killed the leader of the largest plant; rounding the Cape, when the cabin temperature dropped to $38^{\circ} \mathrm{F}$ and a parrot perished, Crinum and Haemanthus plants, as well as Boronia microphylla died in the frost and snow, though a species of Brachychiton and the Moreton Bay jasmines ('J. bidwillii' and an unnamed climbing one with ternate leaves) did not suffer, two of the bunya-bunya trees having produced new shoots though no planted seeds had germinated, and his gladioli seemed to be coming into flower at sea. He also had New Zealand plants, but he feared for them in crossing the tropics and had fixed up blue calico blinds on the cases so that they could be drawn down over the sunny side. To while way the time he got a fellow passenger to teach him the rudiments of drawing.

With the surviving plants and a letter of introduction from King he met Sir William Hooker, now Director of Royal Botanic Gardens Kew, who published Araucaria bidwillii in volume 2 of his London Journal of Botany (1843: 498, tt. 18, 19). Hooker acknowledged 'J.T. Bidwill' as having sent material to the Linnean Society of London (Australian Herbarium now dispersed, largely to Kew in 1915), and now bringing not only dried material but also a living specimen to England. By reference to his herbarium specimens sent to Hooker, he was able to establish his priority in the New Zealand plant discoveries. He gave (probably for exchange) seeds of many plants to Hooker for the gardens at Kew ${ }^{18}$ but many of his most striking imports were put into a sale held by the natural history auctioneer, J.C. Stevens, in London on 18 July $1843^{19}$. This sale included plants sent from Guatemala, principally orchids which fetched a high price and eclipsed Bidwill's lots. Although his new species of Dendrobium, D. kingianum (Orchidaceae), the variable pink rock orchid named after King by Bidwill (though published by Lindley) and held to have been collected in the Buckets west of Gloucester in 1839 (Adams \& Lawson 1995: 1), went to Loddiges ${ }^{20}$ for $£ 410 /-$, the Araucaria bidwillii was bought in at 20 guineas, as was 'an extraordinary plant of Acrostichum grande' for 10 guineas. Lots that sold included one of the jasmines at $£ 1$ 18/- and, from New Zealand, his Easter orchid collected near Rotorua, Earina autumnalis (E. suaveolens) which went again to Loddiges ${ }^{21}$ (both this and the Dendrobium appear in Loddiges's 1844 catalogue of orchids) for $£ 28 /-$ and three species of Clematis, one at $£ 16 /-$, another $£ 12 /-$ and a third at $£ 112 /-$. Small seedlings of a 'Dacrydium' sp. went for $£ 16 /-$ each. Later he seems to have tried to persuade the Dukes of Northumberland (Syon House) and Devonshire (Chatsworth) to take some of the withdrawn lots but it is unclear whether these collectors bought his plants, especially the 'Acrostichum', i.e. Platycerium, which may have gone to Veitch at Exeter ${ }^{22}$. However, it may well have been the 'Acrostichum grande', i.e. Platycerium superbum, Queen Victoria much admired during one of her frequent visits to Kew ${ }^{23}$, for John Smith ${ }^{24}$ noted that when the living plant of the bunya-bunya pine sent by woodcutters at Moreton Bay to Bidwill with a reserve of $£ 25$ [sic] but with no bids was bought in he got it for Kew where it was some $4 \mathrm{~m}$ tall by 1863 , when it was moved to the 'Winter Garden' where it later bore cones.

During his stay in Britain, Bidwill went to see Robert Brown at the British Museum ${ }^{25}$ and Hooker introduced him to Dean Herbert ${ }^{26}$, the acknowledged expert on plant hybridization and especially on many petaloid monocotyledons, who later commemorated Bidwill in the genus Bidwillia (= ?; see Appendix). In the autumn of 1843, Herbert gave him live material including seeds of several Gladiolus species, three of them including G. imbricatus being allegedly new to Australia: some of the resultant seedlings raised in NSW were passed on to King in due course ${ }^{27}$. Many of Bidwill's hybrid gladioli raised in Australia were rare in Britain ${ }^{28}$ but his supposed cross between species of Crinum and Amaryllis was thought by Herbert to be merely a young plant of C. flaccidum, so, at Herbert's suggestion (it would not flower for many years), Bidwill took it back to Australia! Herbert later discussed Bidwill's work in print (Herbert 1847). 
Bidwill also corresponded with Smith ${ }^{29}$ about materials he had brought for Kew, apparently with a view to exchange for there is a great deal in the letters on the packing of plant-cases for NSW. The Exeter firm of Veitch was involved in preparing the shipment ${ }^{30}$. Lindley apparently supplied tender pines and other plants from the Horticultural Society, and Loddiges seems also to have been a source, both sending material to Kew to be packed, though Loddiges could not supply a number of things including maté tea (Ilex paraguariensis) and jujube (Ziziphus jujuba), Bidwill hinting that Smith might do so.

\section{New South Wales again}

Bidwill left England on the Arachne and when he returned to NSW in 1844, he brought with him his sister Mary Carne (who married William Macdonnell there in the same year (Bidwill \& Woodhouse 1927, Ch. 14)), a stock of strychnine and an important collection of new plants, especially from Kew, including Araucaria angustifolia ${ }^{31}$, Lilium speciosum, Paulownia tomentosa, and Musa 'cavendishii' ${ }^{32}$ besides roses (only about ten of the original 50 survived the voyage), apples, cherry-plums (that at Camden Park subsequently dying ${ }^{33}$ ) and sweet-kerneled apricots which fruit would dry in the sun. Amongst the seeds were species of Mimulus, Lobelia, passionfruit and Achimenes as well as Clerodendrum speciosissimum and Clivia nobilis, which he offered to King, complete with a supply of strychnine (at $£ 3$ per ounce) for poisoning sheep predators ${ }^{34}$, though James Bowman got two ounces for $50 /{ }^{35}$. The Camden catalogue of 1845 shows that his introduction of Araucaria angustifolia ("A. braziliensis'), Clerodendrum speciossisimum, Clivia nobilis and Lilium speciosum was successful.

He sent plant material back to Herbert ${ }^{36}$ including a hybrid Erythrina raised at Camden (see below) and continued the exchanges with Kew, sometimes passing on seeds to King (Maiden 1908). He was involved with the gardens at Camden, though at least sometimes his dealings were certainly on a commercial basis, his consignments 'put up to the order of' Bidwill apparently charged to him as in August 1844 when an order worth $£ 15170$ included the hybrid 'Erythrina camdenensis' [i.e. E. x bidwillii; see Appendix], wisteria and a case of wine (15/-) for example ${ }^{37}$, suggesting again that at this time Camden was not where he was doing his own experiments. In August 1844, he accompanied Macarthur to Ravensworth, apparently to collect large numbers of Platycerium superbum in the Manning ${ }^{38}$ and in December he could write to King of the hybrid crinums raised at Camden ${ }^{39}$ (Maiden 1908), which are listed in the catalogue of plants growing there in 1845 (pp. 6-7), the Camden catalogues also listing hybrids of Hibiscus and Camellia (some of these original crosses still exist at Camden according to Professor Clough).

Meantime, one of Bidwill's principal interests was still the raising of hybrid gladioli, sending corms and seeds to Bowman and to King, to whom he was giving advice on raising dendrobiums from seed ${ }^{40}$ in October 1844, pointing out that Calochortus (Cyclobothra) albus was coming in to flower as well as his 'roseo-blandus' gladioli hybrids (listed with other hybrids in the 1845 Camden catalogue, p. 7), of which he sent seed with that of other hybrids the following December ${ }^{41}$. His hybridizing was advanced in that he could use dry pollen brought from afar provided that the stigma was moistened beforehand ${ }^{42}$. He later wrote of his experiences in a letter to the Gardeners' Chronicle (27 July 1850 p. 470), 'Vitality of pollen', noting that it was not possible to keep pollen of Amaryllis or Crinum spp. from one season to the next but that it remained viable for more than three months. Gladiolus pollen could not be kept in his experience though that of G. roseus (= ? G. caryophyllaceus) two months old had fertilized G. blandus (= ? G. carneus). Pollen of lilies would not keep at all 
and the only dicotyledon he found with long vitality was a species of Melianthus. He recommended keeping the pollen in paper with dry flannel in tin boxes.

Besides introducing more new plants, including Salpiglossis, he was getting knitting needles for Mrs King and the latest music ('all the rage') from London. His interest in irids was not merely horticultural however, his drawing up discussions on generic delimitation in the group ${ }^{43}$, arguing that Babiana and Antholyza be united, a course which was not followed until 1990. With respect to native plants, his bible was apparently King's copy of Robert Brown's Prodromus (1810), which he borrowed over an extended period ${ }^{44}$. He was suggesting hybridizing the native Nicotiana suaveolens with N. longiflora, a South American species he presumed to be allied, and synthesizing hybrid hibiscus and even jasmines including ' $J$. bidwillii'. He was even hybridizing species of 'Eugenia' (probably Syzygium) and Acmena, though this was the trickiest he had ever attempted, surpassing Aizoaceae and Polygala in difficulty ${ }^{45}$. His introductions at this time included stephanotis, 'a splendid sweet-scented Apocynaceous plant from Madagascar' ${ }^{46}$, which is first listed in the 1845 Camden catalogue (p. 27).

\section{New Zealand again; Tahiti}

During 1844 Bidwill went to New Zealand again 47 , this time being much concerned with the payments for sheep sent out from Ravensworth to Nelson and apparently acting as agent for James Bowman ${ }^{48}$. In February $1845^{49}$ (Herbert 1966) he was sent to Tahiti allegedly on the Coquette on 15 February (Bidwill 1952: 8) but his merchandise at least went there on the $A n n$, his large numbers of packages and sundries being insured for $£ 400^{50}$. From Tahiti, which was undergoing civil unrest as the French had just deposed the Queen, he wrote of the troubles to Emily, wife of James Macarthur ${ }^{51}$ to whom he seems to have been rather attached and for whom he collected shells there.

William Macarthur sent him $£ 37 /$ - worth of citrus, passionfruit, cactus and bougainvillea plants as well as vegetable seeds ${ }^{52}$, though Macarthur had hoped to extract more from James Kidd (a former convict and schoolfellow of Kew's John Smith) at the Botanic Gardens ${ }^{53}$. Bidwill tried in vain to establish commercial passionfruitgrowing on the island (Bidwill 1952: 8). One of his shipments to Macarthur from Tahiti apparently never arrived ${ }^{54}$ though some seeds including those of the papaya, the first in Australia, and hybrid Hibiscus moschatus-speciosus (? Abelmoschus moschatus $\times$ Hibiscus coccineus) did, being sent for collection to the Australian Club of which Macarthur was a founder member ${ }^{55}$ and Bidwill an early one, being on its Committee since December 1841 56; Macarthur had heated greenhouse space for them at Camden. In March 1847, seedlings of the papayas were sent to William Sharp Macleay ${ }^{57}$, son of Alexander McLeay, whose house and botanically rich garden he had taken over in lieu of part of his father's heavy debts; in September 18 papaya plants from Camden were received at the Botanic Gardens ${ }^{58}$. A collection of Tahitian ferns reached Ludwig Leichhardt's friend, Lieutenant Robert Lynd, Barrack Master at Sydney ${ }^{59}$, Lynd proposing to send seeds to both Bidwill and Macarthur from Auckland ${ }^{60}$ in return.

Bidwill sent Tahitian plants to Britain but they were directed to his father in Exeter and were delayed in reaching Kew; once again Lindley was criticized for neglecting his 'rare Tahitian Orchids which I sent him in spirit (at my own expense) on my return thence ${ }^{61}$ (Maiden 1908). Besides the papaya, his introductions to Australia included certain bananas, which he sent to King, and a form of Hibiscus rosa-sinensis which flowered when only $20 \mathrm{~cm}$ tall ${ }^{62}$; he crossed this with ' $H$. liliiflorus', which Macarthur later sent to Hooker and to Lindley ${ }^{63}$. The Sydney Gardens ${ }^{58}$ received some of these bananas and hibiscus including the hybrids in September 1847. 


\section{The Sydney directorship}

In the winter of 1847 , Bidwill was involved in mineral prospecting in New South Wales ${ }^{64}$, visiting Molong and Wellington in appalling snow and ice, praising the Molong mine as a whole hill of copper ${ }^{65}$ and finding a large-fruited 'Casuarina'. In Sydney (?Clovelly, Watson's Bay) he had amassed a collection of Cape Gladiolus and other species of Iridaceae, having been much encouraged by Herbert ${ }^{66}$, though Herbert's death that year deprived him of his most important correspondent. He also had a flowering 'Erythrina carnea' but it did not have flesh-coloured flowers and was very different from any seen before ${ }^{67}$. Now Bidwill was asking Hooker for correspondents to enlarge his collection (he had 21 species of Gladiolus and many hybrids) but he was also soliciting Hooker's support in his nomination by the new Governor Sir Charles Augustus FitzRoy (Captain Robert FitzRoy's half-brother), to manage the Sydney Gardens.

The death in June 1839 of Allan Cunningham (b. 1791) in Sydney after his return from New Zealand was followed by a decline in the fortunes of the Botanic Gardens in Sydney (Bidwill \& Woodhouse 1927: 115). Under the 'Acting Superintendent' James Kidd, the gardens became neglected. Macarthur, who used to instruct Kidd to supply material from the Gardens for export to Britain in exchange for material apparently sent thence to Camden Park ${ }^{68}$, had proposed Leichhardt ${ }^{69}$ to run them, soliciting Hooker's support, but Alexander McLeay was apparently against the 'German adventurer' and wrote to Hooker to send someone from England (Gilbert 1986: 68). However, Hooker had said that a salary proposed at $£ 200$ was too small, and that it should be at least $£ 300^{70}$. Bidwill, who had returned to Sydney from New Zealand on the Hope in 1839, some three days after Cunningham's funeral, first approached Hooker about the post on his next return from New Zealand in 1844 and later when in Tahiti, he raised it with Macarthur.

With the cessation of transportation in 1840 and collapses in commodity prices, the Colony was in depression and, in July 1844, Kidd was made 'Acting Superintendent' until someone was sent out. Having lost to McLeay over Leichhardt, Macarthur pushed for Bidwill in May $1846^{70}$ as his name had been put before the Committee overseeing the Gardens. The Committee was a subcommittee of that for both the Australian Museum and the Gardens: it included Macarthur, McLeay, King and Deas Thomson (Gilbert 1986: 58). McLeay now put Bidwill's name to Hooker, while Macarthur was pressing him to put it to the Governor, Sir George Gipps. In June, Macarthur was suggesting that on his return from the strife-torn Tahiti, Bidwill should come to Camden Park, all expenses paid, until the appointment was sorted out. The Committee was ready to elect him until the Colonial Secretary's views became known, for 'I think James [Macarthur, then in London] has influence enough with Mr [William E.] Gladstone to bring your qualifications under his favourable notice' ${ }^{71}$. There was still no news in August, when Gipps had been replaced by FitzRoy but Macarthur was still encouraging Bidwill ${ }^{72}$, 'How greatly I should rejoice to see you comfortably situated at the B. Garden'. Then James Bowman died on 23 August 1846 and with Edward at 21 considered too young to run Ravensworth, Macarthur proposed that Bidwill come back from Tahiti to manage the estate on a salary of $£ 200$ a year, living with Edward ${ }^{73}$, though there was still no news from Bidwill by November ${ }^{74}$.

Gladstone asked the new Governor to get a report from Council to see how the declining Gardens could be restored (Gilbert 1986: 71). On 27 February 1847, FitzRoy reported that $£ 200$ salary could be made available for a person from England to take up the post ${ }^{75}$; presumably being aware of Hooker's advice that $£ 200$ would not be appropriate, he added that if no-one could be found in Britain, 'I believe a competent person may 
be found in this Colony'; in a desptach of 3 April he put Bidwill's name ('Bidwell') forward to Gladstone's successor as Colonial Secretary, Earl Grey, and the new Governor and the Legislative Council appointed Bidwill Government Botanist and Director (the first time the title had been used). Bidwill wrote to Hooker ${ }^{76}$ in November 1847 'I have been acting as Director of the Sydney Gardens' since 1 September. He had been appointed some time previously but had waited for the passing of the appropriate act by Council because it had not been clear that Council would vote the available salary of $£ 300$, a sum apparently higher than would have been voted for any other person in the Colony. Indeed it seems that Bidwill had had a role in influencing certain members of Council not to oppose the NSW Colonial Secretary, Edward Deas Thomson, who had privately agreed with Bidwill that the salary should be so exceptionally high. Bidwill's influence probably through Macarthur and McLeay seemed to have been strong because the vote was carried without opposition.

Once in office, Bidwill was writing to King of the labile sexuality of Pittosporum flowers in the Gardens (Maiden 1903, 1908), asking for Dendrobium kingianum pollinia, and noting that Garrya elliptica had been introduced. That King too was getting involved in hybridizing gladioli gave Bidwill continued reason to enthuse ${ }^{77}$. He was sending out sugar-cane cuttings to Macarthur ${ }^{78}$ and was receiving, perhaps from J.G. Boyd, living orchids and other plants from Vanuatu ${ }^{79}$, which he intended to send to Kew as he had no facilities for their cultivation in Sydney; these included a 'Pothos' with leaves like a Strelitzia (probably Epipremnum amplissimum, Araceae ${ }^{80}$, as it has Musaceous venation whereas P. rumphii, the only species of Pothos in the islands, does not), climbers, a 'fleshy-leaved thing' looking like a 'Cacalia' and other succulents; there were also a new Araucaria from New Caledonia and another, possibly new, from Australia. These, with material raised from seeds collected by Leichhardt and Mitchell as well as a plant of his Tahitian form of Hibiscus rosa-sinensis raised at Camden, a plant of Nuytsia floribunda grafted on to a root and Crinum raised from seed collected by Boyd in Vanuatu were all sent off to Hooker in a Camden box borrowed from Macarthur ${ }^{81}$ in December.

As early as 1843 Bidwill had complained to Bowman ${ }^{82}$ that the Gardens had been in decline for five years and now wrote ${ }^{83}$, 'I shall have a great deal of difficulty for some time to do things in a proper way but I have written to England to Dr Lindley to send out a good gardener who I hope to be able to put in Kidd's place [Kidd was redesignated 'overseer' on Bidwill's appointment (Maiden 1906, Froggatt 1932)] as soon as he chooses to take himself off'. Macarthur reported that under Bidwill the Gardens were 'to be completely remodelled and reformed' ${ }^{84}$.

But Bidwill was to be Director for only a few weeks. The Colonial Office in London had also set about finding a Director and Grey appointed Lindley's candidate ${ }^{85}$, Charles Moore (1820-1907), who arrived in the following January. To Hooker's annoyance, the Colonial Office had not turned to him at all, but to Lindley (then Professor of Botany at University College London) and J.S. Henslow, Professor of Botany at Cambridge; Macarthur was not even corresponding with Lindley and the canvassing of Hooker by him and McLeay seems to have been ill-targeted. Although Grey had sent his dispatch to Gipps on 10 July $1847^{86}$, the news seems not to have been released by the Governor's office and the perceived effect was like that a few years before in the case of Charles Sturt (who was offered the post of SurveyorGeneral in South Australia in 1838 but an appointee from London was given the job and Sturt was offered that of Assistant Commissioner of Crown Lands instead [Gibbney 1966]), so that the local appointment seemed to have been overturned in favour of that made by London. In this case the confusion of the apparently crossing despatches led Grey in his despatch of 15 September to refer tersely to his earlier instruction ${ }^{87}$ but it is not clear whether the Colonial Office had intelligence of the machinations of Macarthur and the Committee before discounting an approach to 
the embroiled Hooker. In January 1848 Bidwill appeared in FitzRoy's despatch to Grey as eligible for public appointment having been 'Acting Colonial Botanist' ${ }^{88}$.

Bidwill continued in his November letter ${ }^{89}$ to Hooker, Imagine then my disgust at seeing in [Lindley's] Gardeners' Chronicle of the 3rd July [p. 439] a paragraph stating that $\mathrm{Mr}$ Charles Moore was appointed to the Gardens at Sydney - I know nothing of Mr C. Moore but I can assure his friends that he must be a very discerning person indeed if the Council vote his salary next year - there are plenty of late precedents in this Colony to show that the Government here is not strong enough to carry money votes for Officers even if appointed by the Colonial Secretary in Downing Street I write this purposely before I see Mr Moore because I do not wish to be biased for or against him before I tell you the facts of the case \& to show you that if Mr Moore finds himself in difficulties when he comes here he will have his friends in England to thank for it - Here am I, a person who has done a great deal for Gardening \& the advance of Botany in this Colony, who has introduced more plants at my own expense than almost any other person ... in fact have always been employed for the benefit of my fellow colonists in this way - I am consequently nominated by the Legislative Council of the Colony to fill a situation which will enable me to continue [that] which my reduced means [would not otherwise allow]'. Even though he considered that Moore had never done anything for the Colony nor even England (he was a Scot), Bidwill was prepared to do what he could in the matter of the salary for Moore but if he is a nobody appointed mainly through political influence, why he may take his chance'.

In January he wrote again to Hooker ${ }^{90}$ as Hooker had sent copies of letters relating to the Moore affair to Bidwill's father, but also explaining that the contents of a case of plants sent from Kew, save a few gladioli had perished in transit, Bidwill explaining that they should not be crowded or wet when the cases are sealed. Of the Moore affair he wrote, 'When the Governor heard that through his mismanagement, I had been suspended in my situation at the Gardens he expressed himself very much annoyed at it and said he would give me something else - I asked him to appoint me Commissioner of Crown Land at Wide Bay [now part of Queensland] to the extreme north of the Colony', which he duly did, in November $1848^{91}$. Despite this he was still asking Hooker for plants for the Colony, mainly fruit trees including Brazil nuts but also Mexican pines and Hedychium gardnerianum, now naturalized in NSW and Queensland.

On Moore's arrival, Bidwill wrote once more to Hooker explaining that he had tried to be helpful but 'I do not expect he will prove to be the very best sort of person who could have been sent - he appears to me to only know what he has been taught and not to have any real knowledge of botany, nor has he any enthusiasm' ${ }^{\prime 2}$. In February 1848, he returned to New Zealand for two months ${ }^{93}$ and sent Hooker material including descriptions of conifers and other trees ${ }^{94}$; he had already bought and now sent some of the dried plants collected in Australia by Mitchell which Hooker may not have seen before as they had all gone to Lindley. Indeed Bidwill had complained of the inaccessibility of Mitchell's plants in his earlier correspondence.

Macarthur, sending two seedlings of Araucaria bidwillii he had raised from seeds with notes on their germination, wrote to Hooker ${ }^{95}$ 'What a pretty mess they have made with the appointment of Mr Moore at the Botanic Gardens'. Bidwill got a $£ 300$ salary in his new post and Council 'expressed themselves strongly' about his being superseded by Moore whose 'excessive arrogance \& conceit wanted taking down' ${ }^{96}$ and there followed some regrettable verbal exchanges. He now wrote to Lindley for the first time $^{97}$ with a case of living material including seedlings of $A$. bidwillii and Bidwill's hybrid Hibiscus (these also being sent with many plants of Dendrobium kingianum to Loddiges, Bidwill having sent four A. bidwillii plants to the Calcutta Botanic Garden, 
herbarium specimens from which are preserved at Kew) offered in exchange for desiderata at Camden Park. He remarked, 'We have lately met with a great disappointment in the removal of Mr Bidwill from the situation of 'Director' of the Sydney Botanic Garden ... in his removal I assure you we feel as if we had our right hand lopped off'. No doubt wishing to ingratiate himself with the apparently influential Lindley, he did not blame Moore or Lindley, suspecting that Grey seeing vacillation in the Colony had set about filling the position with a person recruited in the British Isles. However, Bidwill ${ }^{98}$ eventually conceded that Moore was getting on 'tolerably well' but was wasting 'his time in making useless alterations in the layout of the Gardens'. Although Moore received the $£ 300$ salary in 1848 (but he had to pay his passage out), it was reduced to $£ 200$ thereafter ${ }^{99}$, 'so much for Downing Street meddling'.

According to Norton (1901) the trustees of the Museum retired from the management of the Gardens and Bidwill's friends were out for revenge. Sir Stuart Alexander Donaldson mooted the reduction of the annual parliamentary vote for the Gardens' running expenses to $£ 150$. He failed in not only this but his attempt to get them cut up and sold off as allotments. Even so, Moore was to have a trying time for the next few years. In May 1848 Bidwill was back in Sydney ${ }^{100}$ complaining that the support he had solicited in England for the Wide Bay post had seemed not to be forthcoming but that if he got it he would send Hooker plants from there. His pained remarks on the state of the Gardens are telling, 'The Sydney Gardens will always remain what they have been hitherto - a very good place for the Sydney people to walk in of a Sunday \& for the nurserymaids during the rest of the week'.

\section{Wide Bay}

Before moving to Wide Bay, Bidwill went to Bathurst to buy, with others, Thomas Icely's mining property which allegedly had a mile of lode ${ }^{101}$. In November he left by steamer for Newcastle on his way to the Brisbane River and thence to the Mary River, Wide Bay ${ }^{102}$ (Lennon 1924). At first there was only salt beef and bread to eat but he had one sweet potato plant and seven yams planted by January 1849 (Bidwill \& Woodhouse 1927: 116). The land was flat but he wrote that 18 miles up the river a lagoon is covered with water lilies [Nymphaea gigantea], the flowers of which of a most beautiful blue colour, are a foot in diameter!'.

The first settlement at Maryborough is now the suburb of Baddow and Bidwill established at Tinana Creek what he hoped would become a botanic garden, though there were difficulties particularly with drunkenness and other problems with the men sent to help establish the settlement (Bidwill \& Woodhouse 1927: 116). Professor Clough tells me that the first sentence imposed in the Circuit Court was a horsewhipping for one J.D. MacTaggart who had assaulted Bidwill himself. Moreover, in 1849 the settlement was attacked by more than 200 Aborigines ${ }^{103}$; Bidwill almost lost his life ${ }^{104}$ but his botanical keenness was undimmed. He had sent material to Kew in the Camden cases, which included two more living bunya-bunya pines in $1848^{105}$, the case being returned in May 1849 ${ }^{106}$; his request for fruit trees (Bidwill \& Woodhouse l.c.) and later a case of succulents was granted when such was sent out in October $1849^{107}$. He sent material including seeds and orchids to the Sydney Gardens (Gilbert 1986: 82) as well as to Macarthur, whose catalogue of plants grown at Camden in 1850 includes orchids and 'Dammara sp.' (probably Agathis robusta; see below) from Wide Bay, though he would not let T.W. Shepherd's nursery have seed (but see below), it all going to his patron Macarthur. He may have been the first to plant sugar-cane in Queensland (Hewitt et al. 1964) and his salary rose with time, to $£ 500$ per annum in 1849 for work he considered merely pleasure (Maiden 1908); he eventually had an ' 800 acre paddock' there ${ }^{108}$ with two gardens, one near his house 
and a second at the junction of the creek. Allegedly he 'ran' the whole settlement, being not only Commissioner but also Clerk of Petty Sessions and Harbour Master besides performing marriages and reading burial services (Lennon 1924: 19).

On 2 January that year Bidwill wrote to King from the Mary River (the letter, from 'J.S. Bidwill' being printed in Hooker's J. Bot. 1(1849)284-6 under 'Another coniferous tree detected in Australia') about his triumph in finding the day before what is now called Agathis robusta. In 1842, an Aboriginal at Moreton Bay had told him that there was such a tree. No-one else could attest to this, but Bidwill persisted and found it on the site of the future Maryborough; to get the one cone on it, the huge tree had to be felled. By the end of March ${ }^{109}$, he could write to King that he was building his house in what had been a wood of Agathis robusta. He seemed to have mellowed over the Moore affair for, as King was now bound for England, Bidwill wrote, 'By the by, try to find out what was Lindley's reason for appointing Moore, when he could have (one would think) so easily have found a better sort of person - for Moore is an ass, and a very conceited ignorant one too - and as his appointment was really a good thing for me, I may say so now, without fear of thinking I am prejudiced against him. Lindley is such a crooked minded man that it is impossible to guess what his motives may have been but perhaps Sir W. Hooker may know'. Living material of the 'Dammara sp. Wide Bay' was sent from the Sydney Gardens to Henderson's in London on 1 April 1852 (Hyland 1978) and six plants of 'Dammara new species from North Australia' were sent to England from Camden on Christmas Eve $1854^{110}$, while 'Dammara sp. Le 'Kaurie Tree' de Wide-Bay' was no. 75 of the woods sent from Moreton Bay and Wide Bay to the Paris Exposition of 1855 by Moore (Macarthur \& Moore 1855). A young plant from the Gardens was illustrated in a Sydney periodical in 1857 with the name D. robusta attributed to Moore but that name was not validly published until 1860 when it was based on material made available to Ferdinand von Mueller (by T.W. Shepherd's Nursery in Sydney!). In horticulture it may have been the plant known as $D$. bidwillii.

Maryborough became a township and had its first policeman in 1850 (Hewitt et al., 1964). But without civilized company, Bidwill was lonely and periodically depressed; in his letter to King there is more than a broad hint that he was missing King's daughter, of whom he would have liked to get a daguerreotype made in London if he had been bold enough to ask for it directly. He was in Sydney in April 1850, travelling with Macarthur to Clovelly, Watson's Bay, to see 'poor Anderson' who was ill ${ }^{111}$ but it was from Tinana that he wrote ${ }^{112}$ proposing to send his father a log of an apparently undescribed Acacia sp. ('briggalo', i.e. A. harpophylla), mooted as a furniture timber, for the Great Exhibition of 1851. His father agreed and a log from 'J.G. Bidwell' of 'Zinana' was duly exhibited ${ }^{113}$.

In April 1851, Bidwill set out to mark a road from Maryborough to Brisbane, being 120 miles as the crow flies, the road then existing being twice that long. The Governor had ordered this 'mark-tree line' to shorten the distance travelled by prisoners (Loyau 1897). With him were four men including Bidwill's young 'ward', George Dart who had arrived in 1850 (Lennon 1924: 10). Two horses and a team of bullocks were lost to Aborigines who speared them (Anon. 1856). As rations were low, Bidwill and one Slade started out for the station at Durundur near present-day Woodford (Hewitt et al. 1964) but without Bidwill's compass they wandered for eight days lost in the bush, apparently somewhere near the present-day Kilcoy ${ }^{114}$ without food except for some honey given to them by Aborigines, and one large grub. They were guided and indeed carried to Durundur by the friendly aborigines (McKinnon 1940) but the rest of the party lost everything, including Bidwill's diary, to attacking aborigines. As a result of these experiences, Bidwill's health declined, apparently largely due to kidney problems ${ }^{115}$. Despite the attentions of two local doctors and a third consulted later in Sydney (Loyau 1897, McKinnon 1940), he was never to recover. 
While marking the road, the party had come across the wool of some 2000 sheep which had been taken from a station and eaten by Aborigines (McKinnon 1940). Their line went through what later became the middle of present-day Gympie. While a temporary bridge was being constructed there, Bidwill found gold nuggets, which Dart alleges Bidwill kept in a bottle, though their origin he kept secret. The goldfield was 'discovered' in 1867 and the resulting goldrush boosted the economy of Maryborough thereafter. Dart also alleged that Bidwill found gold at Glastonbury (Loyau 1897, Lennon 1924: 81). Later in $1851^{116}$ Bidwill was camping some 30 miles from the Maryborough settlement but the kidney inflammation was so bad he had to return. He was under constant medical supervision and had a bout of hiccoughs which lasted from 29 August until 9 October. He had an abscess in the perineum and this extended to the rectum for which he was treated with morphine. By October he was reduced to a skeleton and died a painful lingering death at Tinana 16 March 1853, aged 38.

Almost till the end, Bidwill had continued to exchange cases of plants with Kew, a consignment of his desiderata coming out in August 1850 and the case returning with Araucaria and Agathis plants 'many dead' in September $1852^{117}$. He was strong enough to voice criticisms of Moore's (apparently unpublished) treatment of Agathis ${ }^{118}$, as well as to propose a visit to New Caledonia. Early in $1853^{119}$ there was an attempt to add the Moreton Bay District to his responsibilities, so arranged as to give the ailing Bidwill no time to protest, when no-one had yet even succeeded in crossing. the dividing range between the Rivers Mary and Brisbane without immense difficulty, as he himself knew only too well. The drought of that summer almost destroyed his garden and in his last weeks he had no vegetables save sweet potatoes to live on. Expecting to die soon, he wrote a touching and devoutly Christian letter to his parents ${ }^{120}$ (Anon. 1856) on 5 March, explaining that he had hoped to return to England but was now dying, his stomach rejecting even liquids. Whilst at a friend's house, he suffered severe chest pains and thereafter was confined to bed for the last ten days of his life during which his friends, no doubt including Dart who lived at Tinana with him, took it in turns to read to him from the Bible ${ }^{121}$.

His last known letter, in wavering handwriting, was written to William Macarthur the next day (March 6) and the first call on his estate was to be his debt to his patron ${ }^{122}$. After this and other debts arising from 'Dr Anderson's' (?of Clovelly) will, the residue of his estate was to go to his brother in New Zealand ${ }^{123}, \mathrm{C}$. Robert Bidwill, who came across to Sydney on 19 July ${ }^{124}$ and apparently took back some of Bidwill's effects including his letter-book rediscovered in 1925 (Bidwill \& Woodhouse 1927: 116); the rest of his effects except for his extensive wardrobe were sold locally, the land he owned at Port Halswell and Murphy Street Wellington as well as in Sydney being sold cheaply (Bidwill \& Woodhouse 1927, Ch. 14). He was buried in his garden with four bunya-bunya trees around the grave: it was still in good condition in the 1950s on the property ('Bidwill', not to be confused with the Maryborough suburb of that name [Bidwill 1952: 8]) of a Mrs Cran, though Hewitt et al. (1964) report that the spot was marked merely by a plain headstone. His post as Commissioner was not refilled.

Many of the plants commemorating him (see Appendix) were novelties collected in the Wide Bay years. Of his horticultural introductions to Europe from Queensland besides the bunya-bunya pine, Akania bidwillii among others bears his name; it was long grown without flowering at Kew as 'Lomatia bidwillii' (Mabberley 1990: 271) and is conceivably the '19 New Lomatia or a new Myrtacea of some kind' sent with Araucaria plants from Moreton Bay in $1848^{125}$, though it was first formally described in nurserymen's catalogues. Besides Agathis robusta, another striking novelty was 'Victoria fitzroyana', i.e. Nymphaea gigantea Hook. (Lindley 1853), available to Kew as seeds from Carter the seedsman in Holborn in the early $1850 \mathrm{~s}^{126}$, though described from herbarium specimens (his ' 39 ') and a dead tuber sent by Bidwill to Hooker in 1851. On. Bidwill's 
death, most of the plants in the Tinana garden were supposed to have been transferred to Sydney and Moore went to Tinana in the spring of 1853 to look at the garden, but he concluded that it was not worth 'the Expense of purchasing and preserving the collection of plants of the deceased gentleman' (Gilbert 1986: 87). The Garden which had a mango, perhaps the first grown in Australia (McKinnon 1940), no longer exists, but Maryborough City Council is establishing a Bidwill Arboretum in the centre of Maryborough to include some of the plants named after him.

\section{Bidwill's achievements}

Besides his exploration and administrative work in New Zealand and Australia, Bidwill was at the centre of Colonial botany and horticulture, being Macarthur's key expert on the introduction of new plants from abroad and their hybridizing and selection for Australian conditions, as well as the discovery and export of new New Zealand, Tahitian and Australian plants and sometimes even their hybridizing with exotics. Despite his very short tenure of the Directorship of the Gardens, Bidwill seems to have been desperately concerned about their welfare as a scientific rather than merely recreational institution. Not only did he discover many new plants in both Australia and New Zealand as well as Tahiti, the names of some of them commemorating him (see Appendix), but he also introduced many of them live to Europe and in exchange introduced thence and from Tahiti economic plants including papayas and perhaps the mango as well as many ornamentals including stephanotis to the young Colony; he was at the forefront of hybridizing ornamentals, most notably perhaps $X$ Amarygia cvs which are now grown throughout the world.

Living an apparently financially rather precarious existence as a trader and agent, dealing in living plants as well as other goods, he had enjoyed the patronage of his horticultural contacts, notably Macarthur, which had led him to believe he was more or less destined for the Sydney post. He began the job energetically but the precipitate appointment made in ignorance by a new Governor, perhaps under pressure from the domineering Macarthur, after all the careful financial fixing had been arranged, was his undoing; his bitterness is understandable, but his untimely death in the harsh conditions of the early Maryborough settlement seems an unjust end for such a promising scientist.

Bidwill's publications were few, but the importance of his Rambles in New Zealand should not be underestimated. Moreover he was generous with information and much of it contained in his letters was published by others, though his discoveries in New Zealand were perhaps played down. His herbarium specimens are preserved at Kew and also Cambridge (New Zealand material), Berlin, Leiden, Melbourne and Missouri (all Australian plants). Besides in plant names, he is commemorated in the names of a suburb in Maryborough (sometimes incorrectly called Bidwell) and another in Sydney. The latter was laid out in the early 1970s; the names of the streets in the area developed by the Housing Commission north of Manifold Road, east of Popondetta Road and west of Daniels Road act as memorials of the man, his associates, discoveries and other achievements: Bidwill Square, Bidwill Reserve, Carne Way, Exeter Place, Tinana Place, Tongariro Terrace, Wide Bay Circuit, Bunya Road, Pine Crescent, Petrie Close, Ludwig Square, Macarthur Way, Camden Way, King Square, Fitzroy Way, Waterlily Terrace, Acacia Terrace, Cupania Crescent, Capparis Crescent, Jasmine Crescent, Loranthus Crescent, Myrtus Crescent, Amaryllis Way, Molong Way, though perhaps Bidwill would have been less than happy with Kidd Close, Lindley Square and Dieffenbach Terrace! The names seem to have been taken from the biographical sketch by Maiden (1908), which also explains the use of 
Brightman, Mena and Deccan and other names for example. For streets named after plants named after Bidwill see Appendix. He was a brave man who in effect gave his life for Australia and justly deserves such civic recognition but he and his pioneering work certainly deserve scientific rescuing from relative obscurity. There is no known portrait of him so perhaps it is time to commemorate him appropriately with plantings, especially the fruits of his hybridizing, in the Gardens he loved.

\section{Acknowledgements}

I am indebted to the Librarians of the Mitchell Library and Royal Botanic Gardens Sydney, the Librarian and Archivist Royal Botanic Gardens Kew, the Librarian of the Department of Botany in the Natural History Museum, London as well as to Jane Britten of the Woollahra Municipal Library and Philip Hanks of the Australian Club for help in getting access to the MSS and other materials in their care during the preparation of this paper. I am also grateful to Jim Angel, Barbara Briggs, Carrick Chambers, Richard Clough, Alistair Hay, John Murphy, Mary Tindale and Karen Wilson (Sydney), N.E. Gorrie (Maryborough), Marco Roos (Leiden), Peter Green and Nicholas Hind (Kew), Bob Cruden (Iowa City) and Mark Large (Palmerston North) for help over certain points in the text and especially to Anne Sing (Oxford) for seeking out obscure publications in England.

\section{References}

Adams, P.B. \& Lawson, S.D. (1995) Dendrobium kingianum. A unique Australian orchid. (Central Queensland University Press: Rockhampton).

Anderson, A.W. (1958) Bidwill the botanist. Gard. Chron. 144: 28, 31.

Andrews, P. (1970) Chapman, Anne Maria; Chapman, Thomas. P. 78 in Dictionary of New Zealand Biography, vol 1. 1769-1869. (Allen \& Unwin).

Anon. (1856) Dangers of the bush - the late J.C. Bidwill, Esq. Gard. Chron. 1856: 20-21.

Barnard, T.T. (1972) On hybrids and hybridization [in Gladiolus]. J.S. African Bot. suppl. 10: 304-10.

Bidwill, J.C. (1841) Rambles in New Zealand (Orr \& Fitze: London).

Bidwill, J.C. (1952) Rambles in New Zealand [Repr. ed. with new introductory matter] (Pegasus: Christchurch).

Bidwill, W.E. \& Woodhouse, A.E. (1927) Bidwill of Pihautea (Coulls Somerville Wilkie: Christchurch).

Clough, R. (1992) Mr Bidwill's Erythrina. Austral. Gard. Hist. 3(4): 10.

Crosson, R.B. (1989) 'Clovelly' - Watsons Bay. Woollahra History \& Heritage Society Briefs 329.

Froggatt, W.W. (1932) The curators and botanists of the Botanic Gardens Sydney. J. Proc. Roy. Austral. Hist. Soc. 18: 101-133.

Gadek, P.A., Quinn, C.J., Rodman, J.E., Karol, K.G., Conti, E., Price, R.A. \& Fernando, E.S. (1992) Affinities of the Australian endemic Akaniaceae: new evidence from rbcL sequences. Austral. Syst. Bot. 5: 717-24.

Gibbney, H.J. (1966) Sturt, Charles. Pp. 495-498 in A.G.L. Shaw \& C.M.H. Clark (eds), Australian National Dictionary of Biography 1788-1850, vol. 2 (Melbourne University Press).

Gilbert, L. (1986) The Royal Botanic Gardens, Sydney. A history 1816-1985 (Oxford University Press: Melbourne).

Hannibal, L. (1994) The 'Kew Belladonna' and the Multiflora hybrids. Austral. Gard. J. 14(1):44-6 [see also 14(3):14].

Harvey, J.H. (1988) Early nurseries at Exeter. Gard. Hist. Soc. Newslett. 24: 17-19.

Herbert, D.A. (1966) Bidwill, John Carne. Pp. $98-99$ in A.G.L. Shaw \& C.M.H. Clark (eds), Australian National Dictionary of Biography 1788-1850, vol. 1 (Melbourne University Press).

Herbert, W. (1847) On hybridization amongst vegetables. J. Hort. Soc. London 2: 1-28, 81-107.

Hewitt, M., Flynn, M. \& Strong, T.J. (1964) An Outline History of Maryborough (Maryborough, Wide Bay \& Burnett Historical Society).

Hyland, B.P.M. (1978) A revision of the genus Agathis (Araucariaceae) in Australia. Brunonia 1: $103-115$. 
Lennon, J. (1924) Maryborough and District, Queensland (Maryborough).

Lindley, J. (1853) The late Mr. Bidwill. Gard. Chron. 1853: 438

Loyau, G.E. (1897) The History of Maryborough (Pole, Oatridge \& Co.: Brisbane).

Mabberley, D.J. (1978) Herbaria of Allan Cunningham, Robert Heward and others at the Chelsea Physic Garden, London. Taxon 27: 489-491.

Mabberley, D.J. (1985) Jupiter Botanicus. Robert Brown of the British Museum (Cramer: Braunschweig).

Mabberley, D.J. (1989) The Plant-Book [Reprint with corrections] (Cambridge University Press).

Mabberley, D.J. (1990) The significance of the three independent 'Kew' editions of JOHNSON'S Gardener's Dictionary. Feddes Repert. 101: 263-276.

Macarthur, W. \& Moore, C. (1855) Catalogue de collections de bois indigènes [sent to the Paris Exposition] (Paris).

McKinnon, F. (1940) Early pioneers of the Wide Bay and Burnett. J. Hist. Soc. Queensland 3: 90-99.

Maiden, J.H. (1903) The Sydney Botanic Gardens. Biographical notes concerning the officers in charge $V I-V I I I$. (S.T. Leigh: Sydney).

Maiden, J.H. (1906a) Sydney Botanic Gardens. Bull. Misc. Inform. 1906: 205-218.

Maiden (1906b) The bunya-bunya. Sydney Morning Herald 9 June 1906: 5.

Maiden, J.H. (1908) Records of Australian botanists - a) general, b) New South Wales. J. Proc. Roy. Soc. New South Wales 42: 60-132.

Norton, J. (1901) Presidential Address. Proc. Linn. Soc. New South Wales 25: 763-795.

Traub, H.P. \& Hannibal, L.S. (1960) Catalog of Brunsvigia cultivars. Plant Life 1960. The Amaryllis Yearbook: 39-62.

Wakefield, E.J. (1908) Adventures in New Zealand from 1839 to 1844, ed. 3 (Whitcombe \& Tombs: Christchurch).

\section{Notes relating to largely MSS sources}

Abbreviations for manuscript repositories: $\mathrm{BM}=$ Natural History Museum, London; $\mathrm{ML}=$ Mitchell Library, Sydney; RBGK = Royal Botanic Gardens, Kew, England; RBGS = Royal Botanic Gardens, Sydney

1. BM: Robert Brown Pocket Diary 1846 ff. 6 verso -7 verso

2. Gard. Chron. 14 Oct. 1871: 1330

3. cf. Devon \& Cornwall Notes \& Queries 17: 321 (1933)

4. ML: Miller \& Cox Families Papers Corr. 1841-1909 (MSS 1516/1) f. 255

5. ML: DOC 42

6. ML: Remarks on board the barque 'Arachne' of London (MSS 2832)

7. Bot. Reg. 29 Misc.: 61 (1843)

8. RBGK: J.D. Hooker Corr. Rec. 1839-1845 ff. 7, 8

9. RBGK: Bentham Corr. 3 f. 313

10. ML: King Papers 9, Further Papers 1805-1850 ff. 259-264

11. ML: Macarthur Letters $7 \mathrm{ff}$. 19-22

12. ML: Joseph Green Bidwill Corr. 1853-1871 (MSS 1141) ff. 167-8

13. ML: Macarthur Papers 38 (MSS A2934, Sir William Macarthur Letters to James Macarthur 1847-1864) ff. 22f-i

14. ML: PX* D379 f. 21c

15. ML: Macarthur Papers 37(B) (MSS A 2933-2, Sir William Macarthur Letterbook 4 viii 1844-7 vi 1850$) \mathrm{ff} .213-6$

16. ML: W. Macarthur, Catalogue 1845: 6

17. ML: Macarthur Family Papers, Edward Bowman Misc. Letters \& Papers 1843-1851 (MSS A 4297) ff. 7-10

18. RBGK: W.J. Hooker Corr. [Australian Letters 1834-1851] 73 letter 22

19. Gard. Chron. 22 July 1843: 503

20. Bot. Reg. 31 t. 61 (1845)

21. Bot. Reg. 29 Misc.: 61 (1843)

22. RBGK: W.J. Hooker Corr. [Australian Letters 1834-1851] 73 letters 23, 24, 27

23. ML: Macarthur Family Papers 7 ff. 11-14

24. RBGK: John Smith MSS, History of the Royal Gardens Kew esp. f. 438

25. ML: Macarthur Family Papers 7 ff. 11-14 
26. RBGK: W.J. Hooker Corr. [Australian Letters 1834-1851] 73 letters 6, 7, 21

27. ML: King Papers 9 Further Papers $1805-1850$ f. 268

28. ML: Macarthur Family Papers 7 ff. $15-18$

29. RBGK: Kew Collectors XI ff. 55-57

30. ML: King Papers 9 Further Papers $1805-1850$ ff. 340-347

31. RBGK: W.J. Hooker Corr. [Australian Letters 1834-1851] 73 letter 14

32. ML: Macarthur Family Papers 7 ff. 11-18

33. ML: l.c. ff. $31-4$

34. ML: King Papers 9 Further Papers 1805-1850 ff. 265-7

35. ML: Macarthur Family Papers 7 ff. 19-22

36. ML: 1.c. ff. 31-4

37. ML: Macarthur Papers 37 (B) (A 2933-2, Sir William Macarthur Letterbook 4 viii 1844-7 vi 1850) f. 14

38. ML: l.c. ff. $7-8$

39. ML: King Papers 9 Further Papers $1805-1850$ ff. $285-8$

40. ML: 1.c. ff. $269-72$

41. ML: l.c. ff. between ff. $280 \& 281$

42. ML: Macarthur Family Papers 7 ff. $15-18$

43. ML: King Papers 9 Further Papers 1805-1850 ff. 273-6

44. ML: 1.c. ff. $293-6$

45. ML: Macarthur Family Papers 7 ff. $27-30,39-42$

46. ML: King Papers 9 Further Papers $1805-1850$ ff. 289-292

47. RBGK: W.J. Hooker Corr. [Australian Letters 1834-1851] 73 letter 17; ML: Macarthur Family Papers 7 ff. 19-22

48. ML: Macarthur Papers VI James Bowman Misc. Papers concerning stock at Ravensworth 1834-1848 ff. 135-9, 145-53, 159-66

49. ML: King Papers 9 Further Papers 1805-1850 ff. 297-300

50. ML: Papers re Shipping 1806-1877 (A 279) ff. 23, 25

51. ML: Macarthur Papers 4 (A 4346, Emily Macarthur Misc. Corr. 1840-1879) f. 61

52. ML: Macarthur Papers 37(B) (A 2933-2, Sir William Macarthur Letterbook 4 viii 1844-7 vi 1850) ff. $X X$

53. ML: 1.c. ff. 136-7

54. ML: l.c. ff. 141-4

55. ML: 1.c. ff. 189-94

56. ML: Australian Club Minute Book 1838-1845 (MSS 1836/3) f. 271. According to the Candidates Book 13 June 1838 - 12 August 1891 (preserved at the Australian Club) f. 13, he was nominated a member 10 i 1840 by Mcleay (President) and Francis Fisher (Treasurer); he (J.C. Bedwell' [!]) 'was an auditor on 19 May 1841.'

57. ML: Macarthur Papers 37(B) (A 2933-2, Sir William Macarthur Letterbook 4 viii 1844-7 vi 1850) ff. $230-1$

58. RBGS: MS B1 ff. 152-3

59. ML: Macarthur Papers 96 re Dr Ludwig Leichhardt 1844-1850 (A 2992) ff. 5-7

60. ML: 1.c. ff. 24-6

61. ML: King Papers 9 Further Papers $1805-1850$ ff. 367-8

62. ML: l.c. ff. 297-300, 308-11

63. ML: Macarthur Papers 37(A) Sir William Macarthur Letterbook 1844-1874 (A 2933-1) ff. 160-4

64. ML: King Papers 9 Further Papers 1805-1850 ff. 308-11

65. ML: Macarthur Papers 7 ff. 35-8

66. RBGK: W.J. Hooker Corr. [Australian Letters 1834-1851] 73 letters 6, 7, 21

67. ML: Macarthur Papers 7 ff. 35-8

68. ML: Macarthur Papers 37(B) Sir William Macarthur Letterbook 4 viii $1844-7$ vi 1850 (A 2933-2) f. 1

69. ML: 1.c. ff. $2-5$

70. ML: l.c. ff. $136-7$

71. ML: 1.c. ff. $141-4$

72. ML: 1.c. ff. $189-94$

73. ML: 1.c. ff. $195-7$

74. ML: 1.c. ff. 213-6

75. Hist. Rec. Aust. I, 25: 376 
76. RBGK: W.J. Hooker Corr. [Australian Letters 1834-1851] 73 letter 7

77. ML: King Papers 9 Further Papers 1805-1850 ff. 312-31

78. RBGS: MS B2 f. [1 x 1847]

79. RBGK: W.J. Hooker Corr. [Australian Letters 1834-1851] 73 letter 7

80. Alistair Hay, pers.comm., cf. Telopea 5: 299 (1993)

81. RBGS: MS B2 ff. [5 xii 1847]

82. ML: Macarthur Family Papers 7 ff. $15-8$

83. ML: l.c.: ff. $35-8$

84. ML: Macarthur Papers 37(B) (A 2933-2, Sir William Macarthur Letterbook 4 viii 1844-7 vi 1850) f. 296

85. RBGK: John Smith MSS, History of the Royal Gardens Kew f. 607

86. Hist. Rec. Aust. 1, 25: 657

87. tom. cit. 752

88. op. cit. $26: 165$

89. RBGK: W.J. Hooker Corr. [Australian Letters 1834-1851] 73 letter 7

90. RBGK: 1.c. letter 8

91. ML: Papers of Thomas Digby Miller 1836-1860 (MSS 896) f. 100

92. RBGK: 1.c. letter 9

93. ML: l.c. f. 97

94. RBGK: Kew Inwards 1848-1858 ff. 22, 26

95. RBGK: W.J. Hooker Letters [Australian Letters 1859-1865 [sic]] 75 letter 10; ML: Macarthur Papers 37(A) Sir William Macarthur Letterbook 1844-1874 (A 293301) ff. 165-171

96. RBGK: 1.c. letter 11

97. ML: l.c. ff. $160-4,172-6$

98. RBGK: 1.c. letter 13

99. ML: l.c. ff. 177-9

100. RBGK: l.c. letter 21

101. ML: Macarthur Papers 27 James Macarthur In Letters 1847-1856 (A 2923) ff. 35-7

102. ML: Papers of Thomas Digby Miller 1836-1860 (MSS 896) f. 100

103. RBGK: l.c. letter 16

104. ML: l.c. f. 102

105. RBGK: Kew Inwards $1848-58$ f. 13

106. RBGK: Kew Inwards [sic] 1837-43 [sic] f. 142

107. RBGK: 1.c. f. 148

108. RBGK: W.J. Hooker Corr. [Australian Letters 1851-8] 74 letter 30

109. ML: King Papers 9 Further Papers 1805-1850 ff. 340-7

110. ML: MS additions to W. Macarthur, Catalogue 1850 opp. p. 14

111. ML: Macarthur Papers 38 Sir William Macarthur Letters to James Macarthur 1847-1864 (A 2934) ff. 22f-i

112. RBGK: 1.c. 73 letter 5

113. Official Catalogue 2: 989 (1851)

114. ML: Cox Family Papers loose ff., ML MSS 3113

115. Hook. J. Bot. 5: 252 (1853); ML: Macarthur Papers 40 Sir William Macarthur In Letters 1827-57 (A 2936) ff. 158-163

116. ML: Papers of Thomas Digby Miller 1836-1860 (MSS 896) f. 106

117. RBGK: Kew Inwards $1837-1843$ ff. 152-3, 1848-1858 f. 223

118. RBGK: W.J. Hooker Corr. [Australian Letters 1851-8] 74 letter 30

119. ML: Macarthur Papers 40 Sir William Macarthur In Letters 1827-57 (A 2936) ff. 158-63

120. ML: Joseph Green Bidwill Corr. 1853-71 (MSS 1141) ff. 164-5

121. ML: DOC 333

122. ML: Macarthur Papers 40 Sir William Macarthur In Letters 1827-57 (A 2936) ff. 165-6

123. ML: DOC 333

124. ML: Papers of Thomas Digby Miller 1836-1860 (MSS 896) f. 115

125. RBGK: Kew Inwards 1848-58 f. 11

126. RBGK: 1.c. f. 201; Bot. Mag. 78: t. 4647 (1852) 


\section{Appendix: eponymy (with Bidwill material when types)}

Acacia bidwillii Benth. in Linnaea 26: 629 (1855) - Leguminosae (Fabaceae)

Type: Queensland, Wide Bay, Bidwill '93' (K! holo)

Street: Acacia Terrace, Bidwill NSW 2770

Akania bidwillii (Hogg) Mabb., Plant-book. corr. repr.: 707 (1989) - Akaniaceae

Type: Cult. RBG Kew ex Hort Linden 1872 (K! neo selected by Mabb. 1.c.; ill. Bot. Mag. t. 8469 (1912))

X Amarygia bidwillii H.E. Moore in Baileya 19: 164 (1975, 'bidwellii'), i.e. Amaryllis belladonna L. $\mathrm{x}$ Brunsvigia orientalis (Amaryllidaceae), nom. superfl. = ? X Amaristetes ('X A. multiflora' Hannibal, nom. illeg., X Amarygia parkeri (W. Watson) H.E. Moore)

Type: None preserved; see Hannibal (1994) for discussion

[Araucaria bidwilliana Hort. (e.g. T.W. Shepherd, Cat. Pl. Darling Nursery (1851)15, nom. nud.) = seq. (cf. Sieb. \& Voss, Blumeng. ed. 3, 1: 1234 (1895))]

Araucaria bidw illii Hook., London J. Bot. 2: 503, tt. 18, 19 (1843) - Araucariaceae

Type: Queensland, Moreton Bay, $70 \mathrm{mi}$ NW Mt Brisbane, Bidwill (?K, not found)

Aster bidwillii Kuntze, Rev. Gen.: 315 (1891) = Olearia virgata (Hook.f.) Hook.f. (Compositae [Asteraceae])

Type: New Zealand, Nelson, Wairau Pass, Bidwill (K!, syn.)

Austromyrtus bidwillii (Benth.) Burret in Notizbl. Bot. Gart. Berlin 15: 501 (1941) - Myrtaceae Type: Queensland, Wide Bay, Bidwill '22' (K! holo)

Street: Myrtus Crescent, Bidwill NSW 2770

*Bidwillia glauca (Ruiz \& Pavon) Herbert ex G. Don f. in Loudon, Encycl. Pl.: 1344 ('glaucus', 1855); Hereman, Paxton's Bot. Dict., new ed.: 75 (1868) = ? Echeandia sp. (Anthericum glaucum Ruiz \& Pavon), though Bob Cruden (in litt.) suggests that Trihesperus Herbert may have to be revived for $A$. glaucum and its allies

Bidwillia glaucescens Herbert in Lindley, Bot. Reg. 30, Misc.: 90 (1844, 'Bidwellia'); Lindley, Veg. Kingdom: 205 (1847)

Type: Cult. W. Herbert ex 'New England' (?Bidwill), ? not preserved. Although Henderson (Fl. Australia 45 (1987) 419) tentatively referred B. glaucescens to Caesia parviflora R. Br. (Anthericaceae), Herbert distinctly notes that the anthers are versatile, thereby suggesting Asphodelaceae, and he himself considered Bidwillia a possible section of Asphodelus. He also referred to his allied South American genus Trihesperus Herbert (1.c.) both Anthericum glaucum Ruiz \& Pavon (referred erroneously to Bidwillia by Don, see above) and $A$. latifolium Kunth. Moreover, the divaricately branched peduncle, basally swollen filaments and brownish tetrahedral seeds strongly suggest Trachyandra divaricata (Jacq.) Kunth which has been long established in New South Wales; it has been placed in Anthericum but is now referred to Asphodelaceae. However it is found in coastal sand dunes which scarcely matches Herbert's 'elevated tract of table-land called New England'. It may have been that there was some confusion with Bidwill's imported plants (if the material was his at all) but without a specimen or drawing it is perhaps impossible to be sure what Bidwillia really was. Indeed Bidwill himself wrote to Hooker (RBGK: W.J. Hooker Corr. 73, letter 14) on 31 Oct 1848, asking for a description of the plant as he had 'not the least knowledge of the plant in this country'

[Bignonia bidwilliana Regel, Cat. Pl. Hort. Aksakov: 19 (1860), nom. nud., = ?]

Brachychiton bidwillii Hook., Bot. Mag. 85: t. 5133 (1859) - Sterculiaceae

Type: Cult. at Kew from seeds sent from Wide Bay by Bidwill (K! holo)

This may well be Sterculia sp. (Bidwill) of Macarthur's 1850 Camden catalogue (p. 19)

Brachyglottis bidwillii [Hook.f., Fl. N.Z. 2: 342, nom. in synon.] (Hook.f.) Nordenstam in Op. Bot. 44: 29 (1978) - Compositae (Asteraceae)

Type: New Zealand, mountains near Nelson, Bidwill '36' (K! syn)

* Omissions from Index Kewensis 
${ }^{*}$ X Brunsdonna bidwillii Worsley in J. Roy. Hort. Soc. 51 : 65 ('Bidwelli', 1926), nom. superfl. = X Amarygia parkeri (W. Watson) H.E. Moore. See X A. bidwillii above

*Brunsvigia $\times$ bidwillii Hannibal in Pl. Life 5: 134 ('bidwellii', 1949), nom. superfl. = praec. Cladium bidwillii (Stapf) Kuekenthal in Feddes Repert. 51: 148 (1942) = Machaerina bidwillii Clompanus bidwillii (Hook.) Kuntze, Rev. Gen.: 78 (1891) = Brachychiton bidwillii

Columbea bidwillii (Hook.) Carr., Conif. ed. 2: 601 ('Colymbea', 1867) = Araucaria bidwillii Cracca bidwillii (Benth.) Kuntze, Rev. Gen.: 174 (1891) = Tephrosia bidwillii

Cryptocarya bidwillii Meissner in DC, Prodr. 15: 74, 508 (1864) - Lauraceae

Type: Queensland, Wide Bay, Bidwill '38' (K! holo)

Cupania bidwillii Benth., Fl. Austr. 1:460 (1863) = Elattostachys xylocarpa (F. Muell.) Radlk. (Sapindaceae)

Type: Queensland, Wide Bay, Bidwill (K! holo)

Street: Cupania Crescent, Bidwill NSW 2770

Cyrtandra bidwillii C.B. Clarke in DC, Monog. Phan. 5: 272 (1883) - Gesneriaceae Type: Tahiti, Bidwill (K! syn)

Dacrydium bidwillii Hook.f. ex T. Kirk in Trans. N.Z. Inst. 10: 388 (1878) = Halocarpus bidwillii [Dammara bidwillii Hort. ex Gordon, Suppl. Gordon's Pinetum: 28 (1862), nom. in synon.; Carr., Conif. ed. 2: 625 (1867), nom. nud. = ? Agathis robusta (F. Muell.) L.H. Bailey (Araucariaceae)]

Elattostachys bidwillii (Benth.) Radlk. in Sitzb. Math-Phys. Akad. Muench. 9: 502, 601 (1879) = E. xylocarpa

[Erythrina $\times$ bidwilliana Hort. (e.g. T.W. Shepherd, Cat. Pl. Darling Nursery (1851) 25, nom. nud.) $=$ seq.]

Erythrina $\times$ bidwillii Herbert in Lindley, Bot. Reg. n.s. 10: t. 9 (1847)

Type: sent to Herbert at Spofforth, Yorkshire by Bidwill as E. herbacea (female) $\times$ E. cristagalli (male), not preserved.

According to William Macarthur, he raised this at Camden Park and sent it to England as 'E. Camdenii' (Macarthur Papers 37(A) Sir William Macarthur Letterbooks 1844-1874 ff. 160-164, A 2933-1, Mitchell Library), though appearing later in MS (op. cit. 2933-2 f. 14) as 'Erythrina Camdenensis' (as when two plants were sent to Loddiges at Hackney in 1845, though listed as E. Camdeni in the Catalogue of Plants cultivated at Camden published the same year) or 'herbaceocristagalli'. At the time considered the only hybrid legume known (Herbert 1847) and believed by Clough (1992) to be the first ornamental plant developed in Australia and illustrated in a publication

Exocarpos bidwillii Hook.f., Fl. N.Z. 1: 223, t. 52 ('Exocarpus', 1853) - Santalaceae Type: New Zealand, S Island, Wairau Mts, 1000-1500' above plain, Bidwill ' 6 ' (K! holo) Forstera bidwillii Hook.f., Fl. N.Z. 1: 155 (1852) - Stylidiaceae

Type: New Zealand, North Is., 'Tongariro', Bidwill (K! syn)

Furcilla bidwillii (Benth.) Tieghem in Bull. Soc. Bot. France 42: 85, 87, 166 (1895) = Muellerina bidwillii

Halocarpus bidwillii (T. Kirk) Quinn in Austral. J. Bot. 30: 317 (1982) - Podocarpaceae Type: New Zealand, Nelson, Bidwill '130' (K! syn)

${ }^{*}$ Hebe $\times$ bidwillii (Hook.) [Wall in Trans. Proc. N.Z. Inst. 60: 384 (1929), basionym non cit.;] A.W. Hill, Ind. Kew. Suppl. 8: 107 (1933) = Parahebe $\times$ bidwillii

Helichrysum bidwillii Benth., Fl. Austral. 3: 627 (1867) = Ozothamnus bidwillii (Benth.) A. Anderb. Hyptiandra bidwillii Hook.f. in Benth. \& Hook.f., Gen. Pl. 1: 294 (1862) = Quassia bidwillii Jasminum bidwillii Vis. in Atti Real Ist. Venet. Sci. ser. 3, 4: $136(1858-9)=J$. didymum Forster f. subsp. lineare (R. Br.) P. Green (Oleaceae)

Type: Cult. Hort. Patav. (?PAD, not found)

Street: Jasmine Terrace, Bidwill NSW 2770 
Libocedrus bidwillii Hook.f., Handb. N.Z. Fl.: 257 (1864) - Cupressaceae Type: New Zealand, Nelson, Bidwill '126' (K! holo)

${ }^{*}$ Lomatia bidwillii E.G. Henderson, Cat. 1859, n.v.; ex Hogg, Gard. Yearb. 1860: 75 (1860) = Akania bidwillii

Loranthus bidwillii Benth., Fl. Austral. 3: 390 (1867) = Muellerina bidwillii

Machaerina bidwillii (Stapf) Koyama in Bot. Mag. Tokyo 69: 62 (1956, bidwellii') - Cyperaceae Type: Tahiti, 'extreme top behind' Papeete, Bidwill (K! holo)

Mariscus bidwillii (Stapf) J.W. Moore in Bernice P. Bishop Mus. Bull. 102: 20 (1933, 'bidwellii') $=$ praec.

Miliusa bidwillii (Benth.) R.E. Fries in Ark. Bot. n.s. 3: 42 (1955) = Fitzalania heteropetala (F. Muell.) F. Muell. (Annonaceae)

Muellerina bidwillii (Benth.) Barlow in Proc. Linn. Soc. New South Wales 87: 53 (1962) Loranthaceae

Type: Queensland, Wide Bay, Bidwill '2', '17' (K! syn)

Street: Loranthus Crescent, Bidwill NSW 2770

Myrtus bidwillii Benth., Fl. Austr. 3: 275 (1867) = Austromyrtus bidwillii

Ozothamnus bidwillii (Benth.) A. Anderb. in Opera Bot. 104: 89 (1991) - Compositae (Asteraceae) Type: Queensland, Wide Bay, Bidwill ' 110 ' (K [photo!] lecto selected by Burbidge, Austral. J. Bot. 6:244 (1958))

Parahebe $\times$ bidwillii (Hook.) W. Oliver in Rec. Domin. Mus. 1: 230 (1944) - Scrophulariaceae (P. decora Ashwin $\times$ P. lyallii (Hook.f.) W. Oliver)

Type: New Zealand, Wairau, c. 2250', Bidwill '15' (K! holo)

Phrygilanthus bidwillii (Benth.) Eichler in Mart., Fl. Bras. V, 2: 48 (1868) = Muellerina bidwillii

Podocarpus bidwillii Hoibrenk ex Endl., Syn. Conif.: 213 (1847) = P. spinulosus (Sm.) Mirbel (Podocarpaceae)

Type: cult. Hort. Huegel (? W, destroyed)

[Podolobium bidwillianum J. Knight ex J.W. Loudon, Ladies Mag. Gard. 1: t. 8, fig. 4 ('bidwelliana', Aug. 1841 without analysis; 'P. trilobatum var. bidwillianum' [nom. in syn. pro P. berberifolium] G. Don f. in J.W. Loudon, op. cit.: 256, 'bidwelliana', Sept. 1841) = P. ilicifolium (Andr.) Crisp \& Weston (cf. Mabberley 1978)]

Quassia bidwillii (Hook.f.) Nooteboom in Blumea 11: 519 (1962) - Simaroubaceae

Type: Queensland, Wide Bay, Bidwill ' 6 ', '2' (K! syn)

Saccopetalum bidwillii Benth., Fl. Austr. 1: 53 (1863) = Fitzalania heteropetala (F. Muell.) F. Muell. (Annonaceae)

Type: Queensland, Wide Bay, Bidwill '37' (K!, holo)

Samadera bidwillii (Hook.f.) Oliv. in Hook., Ic. Pl. 4, 5: t. 2449 (1896) = Quassia bidwillii

Simaba bidwillii (Hook.f.) Feuillet in Bull. Jard. Bot. Nat. Belg. 53: 510 (1983) = Quassia bidwillii Senecio bidwillii Hook.f., Fl. N.Z. 1: 150 (1852) = Brachyglottis bidwillii

Sterculia bidwillii (Hook.) Benth., Fl. Austr. 1: 228 (1863) = Brachychiton bidwillii

Tephrosia bidwillii Benth., Fl. Austr. 2: 210 (1864) - Leguminosae (Fabaceae)

Type: Queensland, Wide Bay, Bidwill '103', '105' (K! syn)

Veronica $\times$ bidwillii Hook., Ic. Pl. 2, 5: t. 814 (1852) = Parahebe $\times$ bidwillii

Vincentia bidwillii Stapf apud Setchell in Dept. Marine Biol. Carnegie Inst. 20: 112 (1924, 'bidwellii') = Machaerina bidwillii

Xylophyllos bidwillii (Hook.f.) Kuntze, Rev. Gen.: 589 (1891) = Exocarpos bidwillii 